Bull. Chem. Soc. Ethiop. 2020, 34(1), 141-148.

ISSN 1011-3924

(C) 2020 Chemical Society of Ethiopia and The Authors

Printed in Ethiopia

DOI: https://dx.doi.org/10.4314/bcse.v34i1.13

\title{
ISOLATION AND STRUCTURE ELUCIDATION OF A NEW OLEANANE TYPE GLYCOSIDE FROM THE AERIAL PORTION OF CESTRUM NOCTURNUM
}

\author{
Humaira Inayat ${ }^{1,2}$, Ikhtiar Khan ${ }^{1}$, Viqar Uddin Ahmad ${ }^{3}$, Mubeen Rani ${ }^{4}$ and Murad Ali Khan ${ }^{2,5 *}$ \\ Institute of Chemical Sciences, University of Peshawar, Peshawar, Pakistan \\ ${ }^{2}$ PCSIR Laboratories Complex, Peshawar 25120, Pakistan \\ ${ }^{3} \mathrm{HEJ}$ research Institute of Chemistry, University of Karachi, Karachi, Pakistan \\ ${ }^{4}$ Department of Chemistry, University of Karachi, Karachi, Pakistan \\ ${ }^{5}$ Department of Chemistry, Kohat University of Science and Technology, Kohat-26000, \\ Pakistan
}

(Received June 10, 2019; Revised January 3, 2019; Accepted January 9, 2020)

\begin{abstract}
Cestrum nocturnum (Solanaceae) is an ornamental plant cultivated in various parts of the world due to its sweet-scented white flowers. It is commonly called night-blooming Jessamine (Raat ki Rani). The genus is known for its toxicity to feedents. The leaves may cause uneasiness in animals which may lead to severe gastroenteritis. The plant is known to be a rich source of pharmacologically active saponins. Looking to its various pharmacological activities as reported, the plant was explored for the isolation of new phytochemicals. During the process, a new oleanen type glycoside was isolated from the butanolic fraction of the leaves of Cestrum nocturnum and was characterized as 3-O- $\beta$-D-xylopyranoside-olean-12-en-28-oic acid-28-O- $\beta$-arabinopyranosyl(1-3)- $\beta$-D-galacto-pyranosyl-(1-2)- $\beta$-D-glucopyranosyl-(1-4)- $\beta$-D-glucopyranosyl ester, along with two reported compounds nocturnoside A and karativoside A. The structure was elucidated on the basis of $1 \mathrm{D}$ and $2 \mathrm{D}$ NMR and mass spectrometry.
\end{abstract}

KEY WORDS: Cestrum nocturnum, Solanaceae, Leaves, Butanolic fraction, New glycoside

\section{INTRODUCTION}

Cestrum is an important genus of the Family Solanaceae, native to tropical America and Australia and is cultivated in various parts of the world for ornamental purpose due to their sweet-scented white flowers [1]. The genus is known for its toxicity to feedents. The species of this genus have cymose inflorescences that are terminal in position or born axillary and are usually fragrant. There are 175 species belonging to genus Cestrum that are native to tropical America and Australia. In Pakistan four cultivated species of the genus Cestrum exists, that includes $C$. aurantiacum, $C$. diurnum, C. nocturnum, and C. parqui [2]. They are commonly known as Cestrum or jessamine due to their fragrant flowers. Cestrum nocturnum is commonly called night-blooming jessamine (Raat ki Rani) [2-4]. Cestrum nocturnum leaf and flower, if ingested cause uneasiness in animals which may lead to severe gastroenteritis and is larvicidal [5]. The toxicity was assigned to the derivatives of tigogenin, tigonin [6,7] and ursolic acid [8]. The essential oil has demonstrated high disease inhibition efficiency on greenhouse-grown pepper plants [9]. The antimicrobial potential was also reported [10]. Alkaloids, saponins, phenolic compounds, tannins, and flavonoids are reported from the species [6]. Some interesting and high molecular weight saponins have been isolated from the species. Phytochemicals from this genus exhibit wide range of pharmacological significances in skin disorders and treating arterial hypotension. They are also used as antiviral, analgesic, abortive, diuretic, antispasmodic, dyspeptic, smooth muscle relaxant, negative inotropic and chronotropic agent [11-13].

*Corresponding author. E-mail: drmalikhan@yahoo.com

This work is licensed under the Creative Commons Attribution 4.0 International License 
In the course of phytochemical investigations, we isolated a new triterpene glycoside, along with two reported glycosides nocturnoside A [14] and karativoside A [15]. The new structure is a bisdesmosidic glycoside of oleanolic acid [16] with one sugar unit attached at C-3 and other oligosaccharide units to C-28.

\section{RESULTS AND DISCUSSION}

A white amorphous powder (32 $\mathrm{mg})$ was isolated from iso-butanol fraction of Cestrum nocturnum and its molecular formula was determined as $\mathrm{C}_{58} \mathrm{H}_{94} \mathrm{O}_{26}$ (calcd for $\mathrm{C}_{58} \mathrm{H}_{93} \mathrm{O}_{26}$ 1205.342) $[\mathrm{M}-\mathrm{H}]^{+}$from $\mathrm{FAB}$ mass spectrum. Its melting point was $205-215{ }^{\circ} \mathrm{C}$. Hum-IV showed broad absorption peaks $\lambda_{\max } 3360$ and $1040 \mathrm{~cm}^{-1}$ in the IR spectrum indicating the glycosidic nature of the compound [17, 18]. The (-ve)-FAB-MS showed a [M-H] at $\mathrm{m} / z 1205.35$ and prominent fragments at $\mathrm{m} / \mathrm{z} 1043$ [(M-H)-162] (cleavage of a hexose unit), 881 [M-H-(162 $\mathrm{x} 2)]^{-}$(cleavage of two hexoses) and 587 [(M-H)-(162 x 3)-132] (three hexoses and one pentose unit). The fragment ion peak at 455 was assigned to the aglycone after the cleavage of three hexose units and two pentose units [(M-H)-(162 x 3)-132- 132]'.

The oleanane-type triterpenoid saponin nature of the isolated compound was revealed through analysis of its spectral features. Seven methyl groups $\left(\delta_{\mathrm{H}} 0.70, \delta_{\mathrm{H}} 0.90, \delta_{\mathrm{H}} 0.94, \delta_{\mathrm{H}} 1.05\right.$, $\delta_{\mathrm{H}} 1.25, \delta_{\mathrm{H}} 1.45, \delta_{\mathrm{H}} 1.48$ ) and vinylic $\mathrm{H}-12$ proton (a multiplet at $\delta_{\mathrm{H}} 5.32$ ) were observed in the ${ }^{1} \mathrm{H}-\mathrm{NMR}\left(400.13 \mathrm{MHz}\right.$, pyridine- $d_{5}$ ) spectrum. ${ }^{13} \mathrm{C}-\mathrm{NMR}\left(125 \mathrm{MHz}\right.$, pyridine- $\left.d_{5}\right)$ showed that the aglycone had seven methyl carbons at $\delta_{\mathrm{C}} 15.10, \delta_{\mathrm{C}} 16.31, \delta_{\mathrm{C}} 17.30, \delta_{\mathrm{C}} 18.30, \delta_{\mathrm{C}} 20.41, \delta_{\mathrm{C}}$ 21.80 and $\delta_{\mathrm{C}} 23.19$, two olefenic carbons at $\delta_{\mathrm{C}} 121.80(\mathrm{CH})$ and $\delta_{\mathrm{C}} 140.03(\mathrm{C})$ and one carbonyl carbon at 178.80 (Table 1).

Table $1 .{ }^{13} \mathrm{C}$ and ${ }^{1} \mathrm{H}$ spectral data of Hum-IV from one and two dimensional experiments.

\begin{tabular}{|c|c|c|c|c|c|c|}
\hline S. No. & ${ }^{13} \mathrm{C}$ & $\delta_{\mathrm{C}}$ & DEPT & Multiplicity & $\delta_{\mathrm{H}}$ & HMBC connectivity \\
\hline 1 & 1 & 39.71 & $\mathrm{CH}_{2}$ & $m$ & $(1 \alpha) 0.92,(1 \beta) 1.71$ & $2 \alpha(1.48), 2 \beta(1.67)$ \\
\hline 2 & 2 & 26.02 & $\mathrm{CH}_{2}$ & $m$ & $(2 \alpha) 1.48,(2 \beta) 1.67$ & $1 \alpha(0.92), 1 \beta(1.71), 3 \alpha(4.53)$ \\
\hline 3 & 3 & 81.10 & $\mathrm{CH}$ & $m$ & $(3 \alpha) 4.53$ & $2 \alpha(1.28)$, Gal $1(4.93), 1 \beta(1.71)$ \\
\hline 4 & 4 & 40.53 & $\mathrm{C}$ & ----- & -- & -- \\
\hline 5 & 5 & 50.16 & $\mathrm{CH}$ & $m$ & $(5 \alpha) 0.95$ & H-9 (1.7), H-24 (0.8) \\
\hline 6 & 6 & 21.16 & $\mathrm{CH}_{2}$ & $m$ & $(6 \alpha) 1.20,(6 \beta) 1.45$ & $(7 \alpha) 1.65, \mathrm{H}-5(0.95)$ \\
\hline 7 & 7 & 32.16 & $\mathrm{CH}_{2}$ & $m$ & $(7 \alpha) 1.28,(7 \beta) 1.65$ & $(6 \alpha) 1.45,(5 \alpha) 0.95$ \\
\hline 8 & 8 & 40.43 & $\mathrm{C}$ & ----- & -- & -- \\
\hline 9 & 9 & 47.50 & $\mathrm{CH}$ & $m$ & 1.28 & H-11 (1.83) \\
\hline 10 & 10 & 37.90 & $\mathrm{C}$ & $\begin{array}{ll}---- \\
--1\end{array}$ & -- & -- \\
\hline 11 & 11 & 32.16 & $\mathrm{CH}_{2}$ & $m$ & $(11 \alpha) 1.78,(11 \beta) 1.83$ & H-9 (1.28), H-12 (5.32) \\
\hline 12 & 12 & 121.80 & $\mathrm{CH}$ & $m$ & 5.32 & $11 \alpha(1.83)$ \\
\hline 13 & 13 & 140.03 & $\mathrm{C}$ & ----- & -- & -- \\
\hline 14 & 14 & 56.49 & $\mathrm{C}$ & ----- & - & -- \\
\hline 15 & 15 & 29.69 & $\mathrm{CH}_{2}$ & $m$ & $(15 \alpha) 1.25,(15 \beta) 1.55$ & $\mathrm{H}-16 \alpha(1.30), 16 \beta(1.44)$ \\
\hline 16 & 16 & 24.07 & $\mathrm{CH}_{2}$ & $m$ & $(16 \alpha) 1.30,(16 \beta) 1.44$ & $15 \beta(1.55), \mathrm{H}-18(4.40)$ \\
\hline 17 & 17 & 45.12 & $\mathrm{C}$ & ----- & -- & -- \\
\hline 18 & 18 & 41.50 & $\mathrm{CH}$ & $m$ & 4.40 & 1.67 \\
\hline 19 & 19 & 39.74 & $\mathrm{CH}_{2}$ & $m$ & $1.67,2.78$ & $\mathrm{H}-18(4.40), \mathrm{H}_{3}-30(1.25)$ \\
\hline 20 & 20 & 40.00 & $\mathrm{C}$ & $s$ & -- & -- \\
\hline 21 & 21 & 32.16 & $\mathrm{CH}_{2}$ & $m$ & $(21 \alpha) 1.48,(21 \beta) 1.50$ & H-30 (1.25), H-22 $\alpha(1.80)$ \\
\hline 22 & 22 & 30.67 & $\mathrm{CH}_{2}$ & $m$ & $(22 \alpha) 1.80,(22 \beta) 1.85$ & $\mathrm{H}-21 \alpha(1.65)$ \\
\hline 23 & 23 & 29.15 & $\mathrm{CH}_{3}$ & $s$ & 1.25 & $(3 \alpha) 4.53$, H-5 (0.95), H-24 (0.82) \\
\hline 24 & 24 & 16.31 & $\mathrm{CH}_{3}$ & $s$ & 1.12 & $\mathrm{H}-23(1.57)$ \\
\hline 25 & 25 & 15.00 & $\mathrm{CH}_{3}$ & $s$ & 0.90 & \\
\hline 26 & 26 & 17.30 & $\mathrm{CH}_{3}$ & $s$ & 0.70 & $\mathrm{H}-7, \mathrm{H}-9$ \\
\hline 27 & 27 & 18.30 & $\mathrm{CH}_{3}$ & $s$ & 1.45 & $\mathrm{H}-15, \mathrm{H}-13$ \\
\hline 28 & 28 & 178.81 & $\mathrm{C}$ & -- & -- & -- \\
\hline
\end{tabular}

Bull. Chem. Soc. Ethiop. 2020, 34(1) 


\begin{tabular}{|c|c|c|c|c|c|c|}
\hline 29 & 29 & 20.41 & $\mathrm{CH}_{3}$ & $S$ & 0.94 & $\mathrm{H}-30(1.48), \mathrm{H}-21 \alpha(1.65)$ \\
\hline 30 & 30 & 23.19 & $\mathrm{CH}_{3}$ & $s$ & 1.25 & $\mathrm{H}-19(1.70), \mathrm{H}-21 \alpha(1.65), \mathrm{H}-21 \beta(1.68)$ \\
\hline 31 & \multicolumn{6}{|c|}{ Xyl. } \\
\hline 32 & 1 & 105.39 & $\mathrm{CH}$ & $d, J=7.6 \mathrm{hz}$ & 5.12 & Xyl. H-2 (4.52) \\
\hline 33 & 2 & 72.66 & $\mathrm{CH}$ & & 4.52 & $\mathrm{H}-3$ (4.53), H-1 (5.12) \\
\hline 34 & 3 & 81.08 & $\mathrm{CH}$ & & 4.53 & $\mathrm{H}-2(4.52)$ \\
\hline 35 & 4 & 68.19 & $\mathrm{CH}$ & & 4.80 & H-3 (4.53), H-5ß(4.30) \\
\hline 36 & 5 & 67.23 & $\mathrm{CH}_{2}$ & & $\begin{array}{l}\text { (Xyl H-5 } 2) 3.64 \\
(\mathrm{Xyl} H-5 \beta) 4.30\end{array}$ & $\mathrm{H}-4(4.80)$ \\
\hline 37 & \multicolumn{6}{|c|}{ Ara. } \\
\hline 38 & 1 & 103.29 & $\mathrm{CH}$ & $t$, distorted & 5.55 & Ara. H-2 (4.13) \\
\hline 39 & 2 & 87.69 & $\mathrm{CH}$ & & 4.13 & Ara. H-1 (5.55), H-3 (3.78) \\
\hline 40 & 3 & 70.05 & $\mathrm{CH}$ & & 3.78 & Ara. H-2 (4.13), H-4 (4.38) \\
\hline 41 & 4 & 68.15 & $\mathrm{CH}$ & & 4.38 & $\begin{array}{l}\text { Ara. H-3 (3.78), } \\
\text { Ara. H-5 } \alpha(4.20), H-5 \beta(4.15)\end{array}$ \\
\hline 42 & 5 & 60.61 & $\mathrm{CH}_{2}$ & & $\begin{array}{l}(\mathrm{H}-5 \alpha) 4.20 \\
(\mathrm{H}-5 \beta) 4.15\end{array}$ & Ara. H-4 (4.38) \\
\hline 43 & \multicolumn{6}{|c|}{ Gal. } \\
\hline 44 & 1 & 103.91 & $\mathrm{CH}$ & $d, J=7.1 \mathrm{~Hz}$ & 4.93 & Gal H-2 (4.58), \\
\hline 45 & 2 & 79.0 & $\mathrm{CH}$ & & 4.58 & $\begin{array}{l}\text { Gal H-1 (4.93), H-3 (4.41), Glc H-1 } \\
(5.18)\end{array}$ \\
\hline 46 & 3 & 69.0 & $\mathrm{CH}$ & & 4.41 & Gal H-4 (4.29) \\
\hline 47 & 4 & 80.55 & $\mathrm{CH}$ & & 4.29 & Gal H-3 (4.41), H-5 (4.10) \\
\hline 48 & 5 & 75.0 & $\mathrm{CH}$ & & 4.10 & Gal H-6 (4.45) \\
\hline 49 & 6 & 68.0 & $\mathrm{CH}_{2}$ & & $\begin{array}{l}(\mathrm{Gal} H-6 \alpha) 4.45 \\
(\mathrm{Gal} H-6 \beta) 4.13\end{array}$ & Gal H-5 (4.10) \\
\hline 50 & \multicolumn{6}{|c|}{ Glc. } \\
\hline 51 & 1 & 104.81 & $\mathrm{CH}$ & $d, J=7.6 \mathrm{~Hz}$ & 5.10 & Glc H-2 (4.08), Gal H-4 (4.29) \\
\hline 52 & 2 & 74.92 & $\mathrm{CH}$ & & 4.08 & Glc H-1 (5.10), Glc H-3 (4.10) \\
\hline 53 & 3 & 78.44 & $\mathrm{CH}$ & & 4.10 & Glc H-4 (3.88) \\
\hline 54 & 4 & 70.01 & $\mathrm{CH}$ & & 3.88 & Glc H-3 (4.10) \\
\hline 55 & 5 & 78.00 & $\mathrm{CH}$ & & 4.08 & $\begin{array}{l}(\text { Glc. } H-6 \alpha) 4.48, \\
(\text { Glc. } H-6 \beta) 4.62\end{array}$ \\
\hline 56 & 6 & 62.30 & $\mathrm{CH}_{2}$ & & $\begin{array}{l}4.48 \\
4.62\end{array}$ & (Glc. H-5) 4.08 \\
\hline 57 & \multicolumn{6}{|c|}{ Glc. I } \\
\hline 58 & 1 & 104.28 & $\mathrm{CH}$ & $d, J=7.7 \mathrm{~Hz}$ & 5.18 & $\begin{array}{l}\text { (Glc. H-2) 4.05, } \\
\text { (Gal. H-2) 4.58 }\end{array}$ \\
\hline 59 & 2 & 74.74 & $\mathrm{CH}$ & & 4.05 & $\begin{array}{l}\text { (Glc. H-1) 5.18, } \\
\text { (Glc. H-3) 4.15 }\end{array}$ \\
\hline 60 & 3 & 78.20 & $\mathrm{CH}$ & & 4.15 & Glc' H-4 (4.18) \\
\hline 61 & 4 & 71.42 & $\mathrm{CH}$ & & 4.18 & Glc' H-5 (3.98) \\
\hline 62 & 5 & 78.41 & $\mathrm{CH}$ & & 3.98 & Glc' H-6 $\beta$ (4.26), Glc' H-6 $\alpha$ (4.51) \\
\hline 63 & 6 & 62.46 & $\mathrm{CH}_{2}$ & & 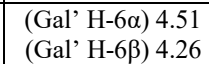 & Glc’ H-5 (3.98) \\
\hline
\end{tabular}

Bisdesmosidic nature of the glycoside was established due to the upfield chemical shift at C28 and the absence of the distinguished carboxyl proton signal at $\delta_{\mathrm{H}} 10-12$, in the ${ }^{1} \mathrm{H}-\mathrm{NMR}$ spectrum [19].

Five monosaccharide unites were indicated through easily distinguishable signals of the anomeric carbons resonating at $\delta_{\mathrm{C}} 105.39, \delta_{\mathrm{C}} 103.29, \delta_{\mathrm{C}} 103.91, \delta_{\mathrm{C}} 104.81$ and $\delta_{\mathrm{C}} 104.28$, having anomeric protons resonating at $\delta_{\mathrm{H}} 5.12(\mathrm{~d}, J=7.6 \mathrm{~Hz}), \delta_{\mathrm{H}} 5.55$ (a distorted triplet), $\delta_{\mathrm{H}}$ $4.93(\mathrm{~d}, J=7.1 \mathrm{~Hz}), \delta_{\mathrm{H}} 5.10(\mathrm{~d}, J=7.6 \mathrm{~Hz})$ and $\delta_{\mathrm{H}} 5.18(\mathrm{~d}, J=7.7 \mathrm{~Hz})$, respectively. $\beta$-Linkage was assigned to all the anomeric protons. The spectra were solved with the help of $J$ - resolve. Very fruitful correlation observations were interpreted from the HMBC spectrum of the compound. The methyl $\left(\mathrm{CH}_{3}\right)$ protons at $\mathrm{C}-29\left(\delta_{\mathrm{H}} 0.94\right)$ showed a strong correlation to carbons at position $19\left(\delta_{\mathrm{C}} 39.74\right), 20\left(\delta_{\mathrm{C}} 40.00\right)$ and $21\left(\delta_{\mathrm{C}} 32.16\right)$. A very prominent correlation was 
detected for the vinylic proton $\left(\delta_{\mathrm{H}} 5.32\right)$ with carbon $11\left(\delta_{\mathrm{C}} 32.16\right)$. The methyl group at position $24\left(\delta_{\mathrm{H}} 1.05\right)$ displayed a correlation with C-4 $\left(\delta_{\mathrm{C}} 40.53\right)$ and C-3 $\left(\delta_{\mathrm{C}} 81.10\right)$. C-27 was distinguished from the carbon 26 , with the help of the correlations it made with $\mathrm{C}-13\left(\delta_{\mathrm{C}}\right.$ $140.03)$ and $\mathrm{C}-15\left(\delta_{\mathrm{C}} 29.69\right)$ in the HMBC spectrum [20].

The assignments for the vinylic $\mathrm{H}-12$ proton at $\delta_{\mathrm{H}} 5.32$ was confirmed by its COSY $-45^{\circ}$ correlations with $\mathrm{H}-11 \alpha\left(\delta_{\mathrm{H}} 1.78\right)$ and $\mathrm{H}-11 \beta\left(\delta_{\mathrm{H}} 1.83\right)$, and in turn the protons at $\mathrm{C}-11$ are showing coupling with $\mathrm{H}-9\left(\delta_{\mathrm{H}} 1.28\right)$. The assignments of protons at position 19 were confirmed by their interactions with $\mathrm{H}-18 \alpha\left(\delta_{\mathrm{H}} 4.40\right)$ and $\mathrm{H}_{3}-29\left(\delta_{\mathrm{H}} 0.94\right)[19]$.

In 2D-COSY interactions, cross-relations between the anomeric protons $\left(\mathrm{Xyl} \mathrm{H}_{\mathrm{I}}\left(\delta_{\mathrm{H}} 5.12\right)\right.$, Gal H-1 (4.93), Glc H-1 (5.10) and Glc' H-1 (5.18)) and the adjacent vicinal protons (Xyl H-2, Gal H-2, Glc H-2 and Glc I H-2) were observed as doublets $(J=7.6,7.1,7.6$ and $7.7 \mathrm{~Hz})$. A distorted triplet was observed for the arabinose anomeric proton at $\delta_{\mathrm{H}} 5.55$. The chemical shifts of the anomeric carbons and the respectively coupled protons were obtained by using HMQC and $\mathrm{HMBC}$ experimental techniques. In the end, 2D-COSY experiments authenticated all the assignments allotted to the atoms in the structure (Figure 1).

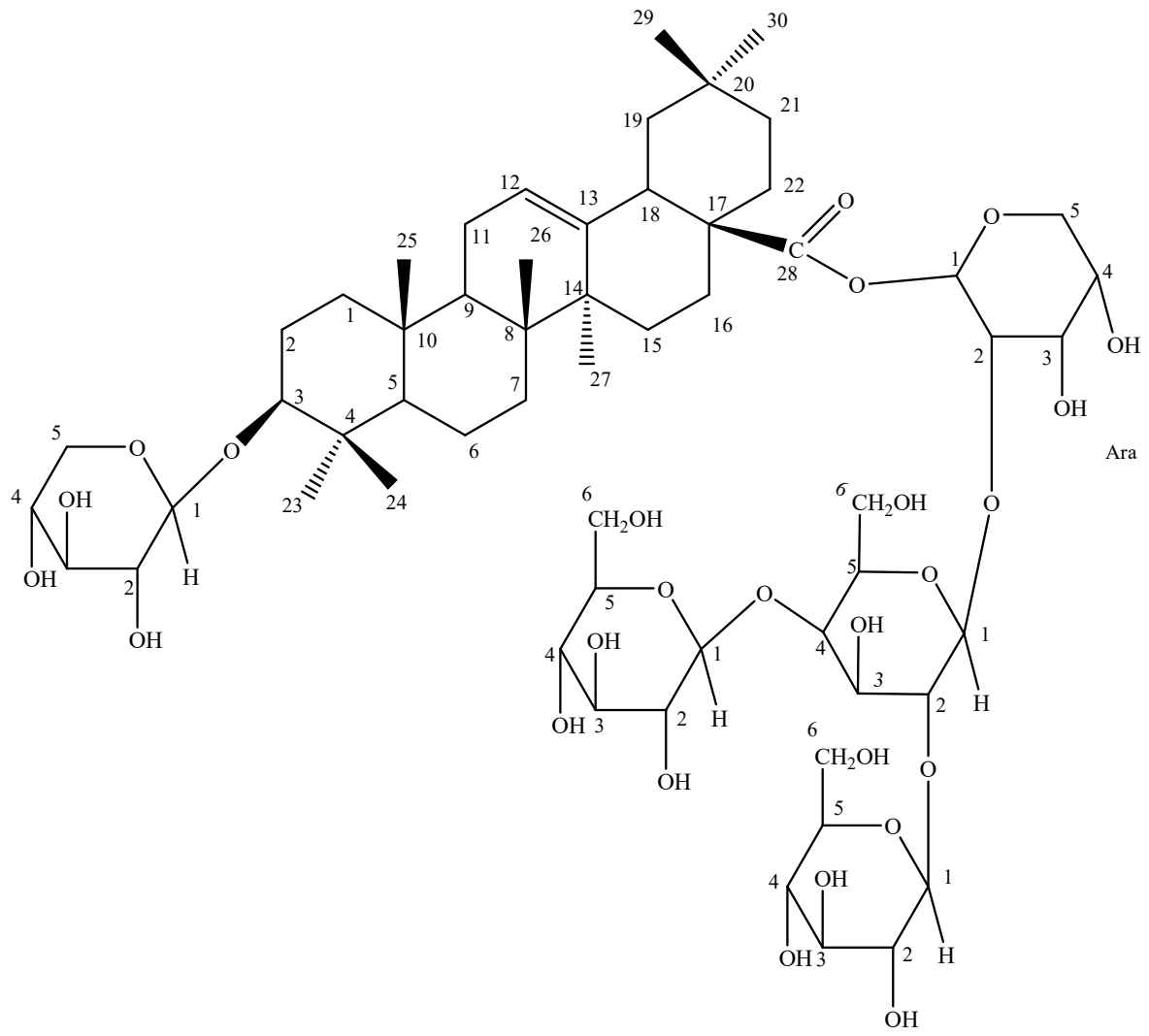

Figure 1. 3-O- $\beta$-D-xylopyranoside-olean-12-en-28-oic acid-28- $O-\beta$-arabinopyranosyl-(1-3)- $\beta$-Dgalactopyranosyl-(1-2)- $\beta$-D-glucopyranosyl-(1-4)- $\beta$-D-glucopyranosyl ester. 
For the identification of monosaccharide, acid hydrolysis of the compound was performed with $20 \% \mathrm{HCl}$. The sugars were identified as xylose, arabinose, galactose and glucoe on the basis of paper chromatography using ninhydrin as visualizing agent [1].

Two other compounds nocturnoside A and karativoside A were also isolated from the plant. All the spectroscopic techniques were applied and the structures of were confirmed by comparing the spectra with the reported data (Figure 2).

\section{EXPERIMENTAL}

Cestrum nocturnum leaves were shade dried crushed and then extracted with methanol. The dried methanolic extract was partitioned with various solvents having different polarities, including, n-hexane, ethyl acetate and iso-butanol. The butanolic fraction was passed through vacuum liquid chromatography, using ethyl acetate-hexane (EtAc/Hex) and then ethanol and ethyl acetate $(\mathrm{EtOH} / \mathrm{EtAc})$ mixed in various proportions and different fractions were collected from $17-45$.

From fraction 32-34 two compounds were isolated using prep-TLC in BAW (butanol: acetic acid: water) 12:3:2 (Figure 2b). Fractions 37-42 were combined (11.61 g) and subjected to column chromatography. The column was eluted with hexane, EtAc/Hxn, EtAc, EtOH/EtAc, $\mathrm{EtOH}$ and $\mathrm{MeOH}$. Fractions from 1-50 were obtained. Fraction 22 was concentrated and on Prep-TLC (12:3:2 BAW) gave a pure compound (Figure 1). Fraction 23 gave a pure compound, white ppt. (Figure 2a). Scheme 1 shows the isolation of various compounds from Cestrum nocturnum.

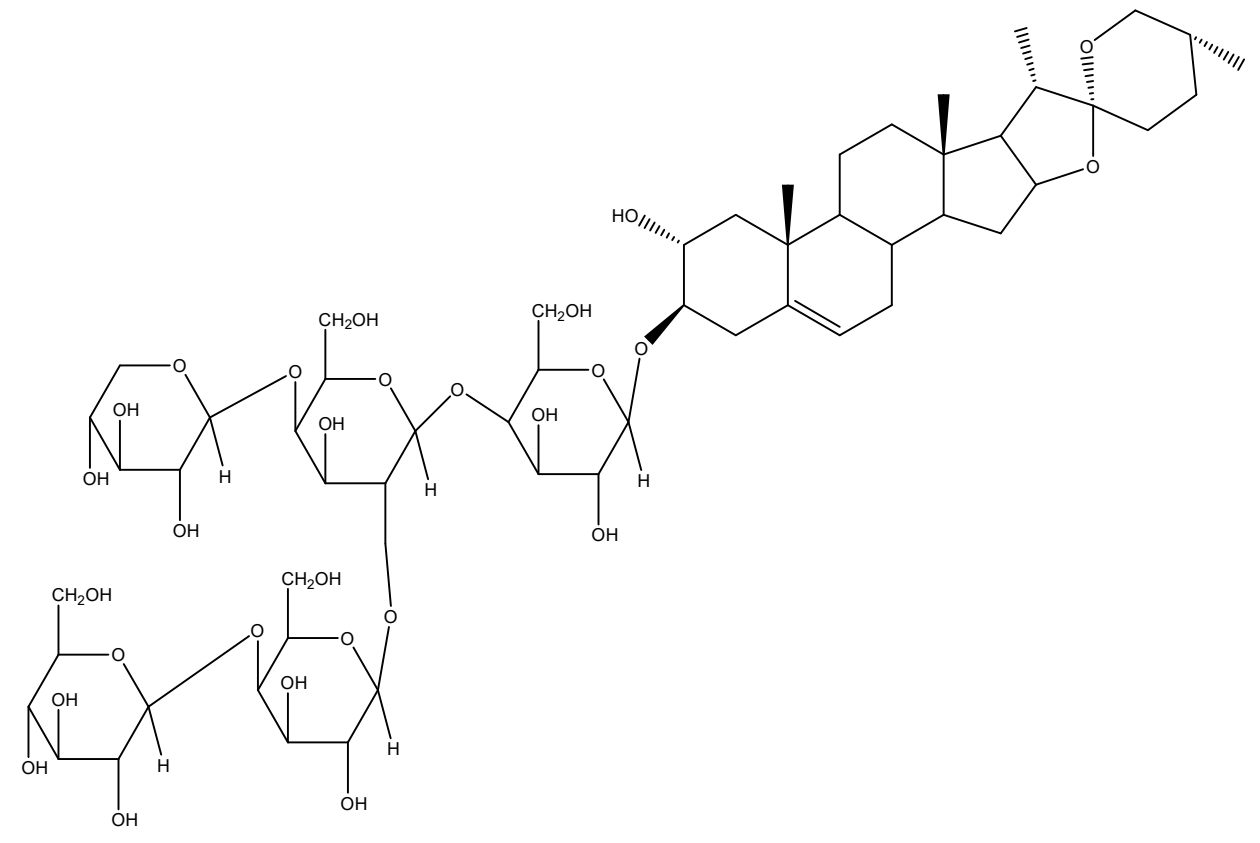

Nocturnoside A 


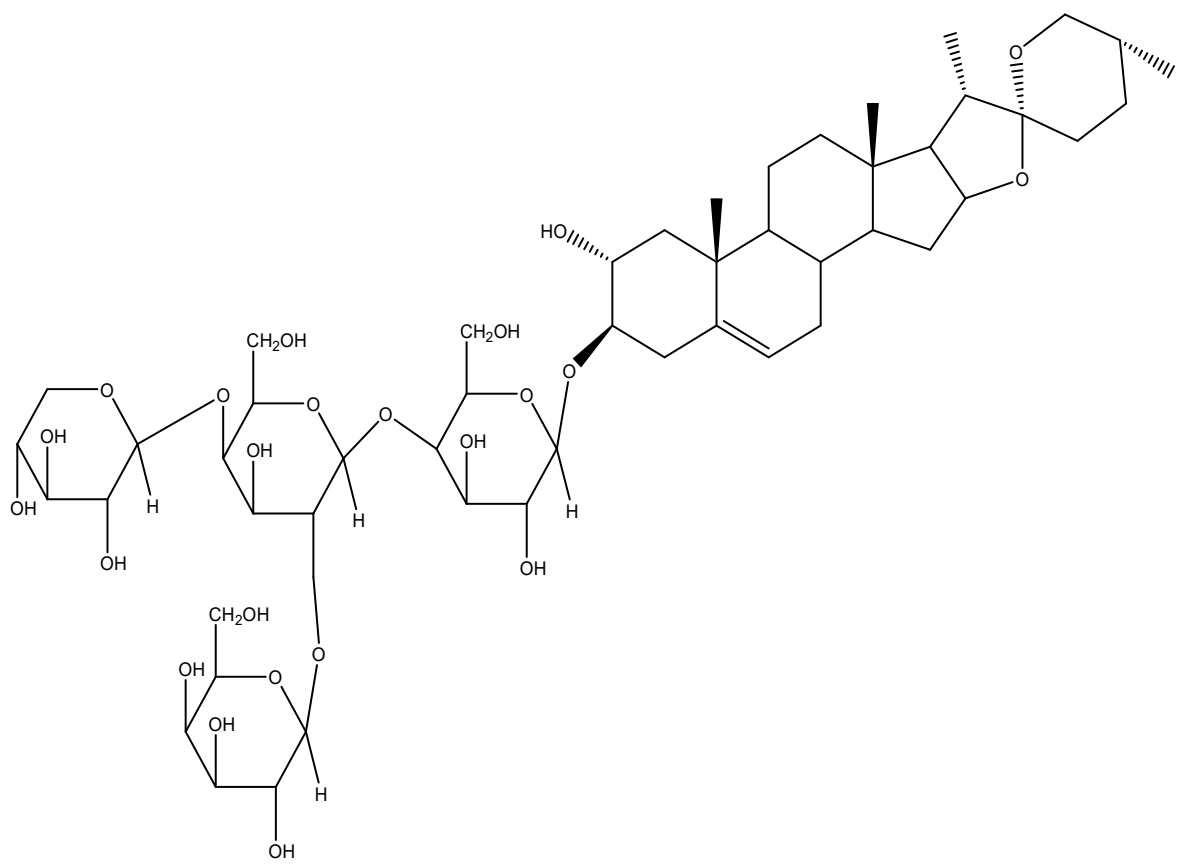

Karativoside A

Figure 2. (a) Nocturnoside A and(b) karativoside A.

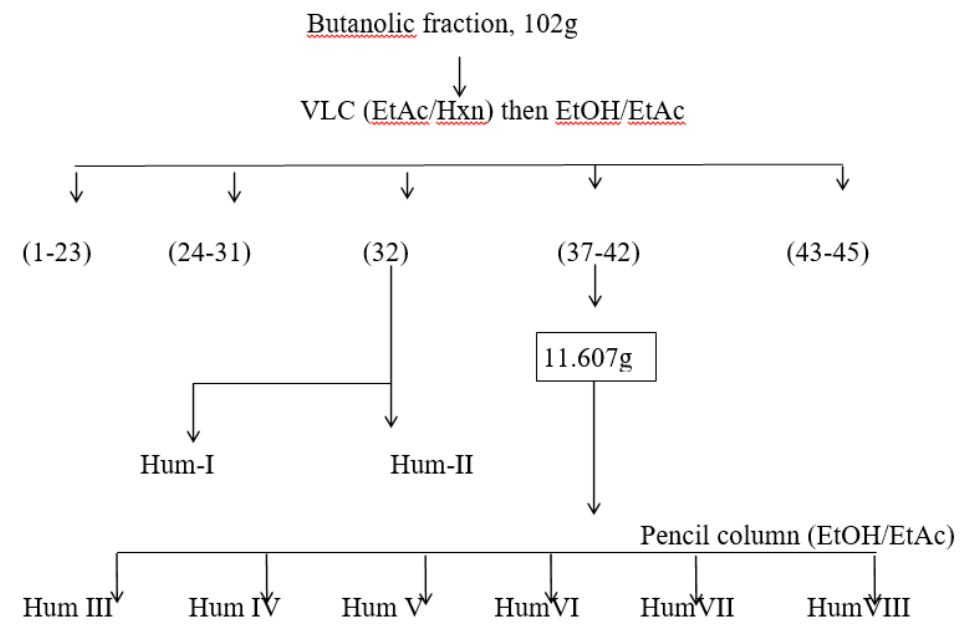

Scheme 1. Extraction and isolation of compounds from Cestrum nocturnum.

Bull. Chem. Soc. Ethiop. 2020, 34(1) 


\section{ACKNOWLEDGMENT}

We are grateful to Dr. Viqar Uddin Ahmad (HEJ, Karachi, Pakistan) and Dr. Mushtaq Ahmad (PCSIR Labs Complex, Peshawar) for their help in characterization.

\section{REFERENCES}

1. Baqai, F.T. Phytochemical studies of Cestrum species (Family Solanaceae). Ph.D. Thesis, HEJ Research Institute of Chemistry, University of Karachi, Karachi, Pakistan; 1999.

2. Nasir, Y.J. (Ed.). Solanaceae, Pakistan Agricultural Council: Islamabad; 1985.

3. Muller-Ebeling, C.; Ratsch, C.; Shahi, S. Shamanism and Tantra in the Himalayas in Rochester, Vt: Inner Traditions, Inner Traditions, Rochester: New York; 2002.

4. Watt, J.M.; Breyer-Brandwijk, M.G. The medicinal and poisonous plants of southern and eastern Africa: Being an account of their medicinal and other uses, chemical composition, pharmacological effects and toxicology in man and animal. E. \& S. Livingstone: Edinburgh; 1962.

5. Choudhury, C.; Devi, M.R.; Bawari, M.; Sharma, G.D. Ethno-toxic plants of Cachar District in Southern Assam with special reference to their medicinal properties. Assam University $J$. Sci. Technol. Biol. Environ. Sci. 2011, 7, 89-95.

6. Patil, C.D.; Patil, S.V.; Salunke, B.K.; Salunkhe, R.B. Bioefficacy of Plumbago zeylanica (Plumbaginaceae) and Cestrum nocturnum (Solanaceae) plant extracts against Aedes aegypti (Diptera: Culicide) and nontarget fish Poecilia reticulata. Parasitol. Res. 2011, 108, 1253 1263.

7. Chakravarty, R.N.; Datta, S.; Mitra, M.N. Tigogenin and ursolic acid from Cestrum diurnum Linn. Experientia 1963, 20, 200-201.

8. Karawya, M.; Rizk, A.; Hammouda, F.; Diab, A.; Ahmed, Z. Phytochemical investigation of certain Cestrum species. General analysis, lipids and triterpenoids. Planta Med. 1971, 20, 363-367.

9. Al-Reza, S.M.; Rahman, A.; Ahmed, Y.; Kang, S.C. Inhibition of plant pathogens in vitro and in vivo with essential oil and organic extracts of Cestrum nocturnum L. Pestic Biochem. Physiol. 2010, 96, 86-92.

10. Khan, M.A.; Inayat, H.; Khan, H.; Saeed, M.; Khan, I.; Rahman, I. Antimicrobial activities of the whole plant of Cestrum nocturnum against pathogenic microorganisms. Afr. J. Microbiol. Res. 2011, 5, 612-616.

11. Munoz, V.; Sauvain, M.; Bourdy, G.; Callapa, J.; Rojas, I.; Vargas, L.; Tae, A.; Deharo, E. The search for natural bioactive compounds through a multidisciplinary approach in Bolivia. Part II. Antimalarial activity of some plants used by Mosetene indians. J. Ethnopharmacol. 2000, 69, 139-155.

12. Uddin, M.E.; Ahmad, T.; Arif-uz-Zaman, M.; Rahman, T.; Ranjan, N.; Nazmuzzaman, M.; Manik, M.A. Standardization and improving of in vitro micropropagation of night jasmine (Cestrum nocturnum L.). Plant Archives 2016, 16, 279-284.

13. Fales-Williams, A.; Sponseller, B.; Flaherty, H. Idiopathic arterial medial calcification of the thoracic arteries in an adult horse. J.Vet. Diagn. Invest. 2008, 20, 692-697.

14. Ahmad, V.U.; Baqai, F.T.; Fatima, I.; Ahmad, R. A spirostanol glycoside from Cestrum nocturnum. Phytochemistry 1991, 30, 3057-3061.

15. Vollermer, Yu.S.; Gorovits, M.B.; Gorovits, T.T.; Abubakirov, N.K. Steroid saponins and sapogenins of Allium XIV. The structure of karatavoiside A. The structure of karatavoiside A. Chem. Nat. Compd. 1978, 14, 630-635. 
16. Lenta, B.N.; Ngouela, S.; Noungoue, D.T.; Tsamo, E.; Connolly, J.D. Symphonin: A new prenylated pyranoxanthone with antimicrobial activity from the seeds of Symphonia globulifera (Guttiferae). Bull. Chem. Soc. Ethiop. 2004, 18, 175-180.

17. Wall, M.E.; Eddy, C.R.; McClennan, M.L.; Klumpp, M.E. Detection and estimation of steroidal sapogenins in plant tissue. Anal. Chem. 1952, 24, 1337-1341.

18. Eddy, C.R.; Wall, M.E.; Scott, M.K. Catalog of infrared absorption spectra of steroidal sapogenin acetates. Anal. Chem. 1953, 25, 266-271.

19. Seebacher, W.; Simic, N.; Weis, R.; Saf, R.; Kunert, O. Spectral assignments and reference data complete assignments of ${ }^{1} \mathrm{H}$ and ${ }^{13} \mathrm{C}$ NMR resonances of oleanolic acid, 18a-oleanolic acid, ursolic acid and their 11-oxo derivatives. Magn. Reson. Chem. 2003, 41, 636-638.

20. Štujbera, M.; Sohretoglub, D.; Liptaja, T. NMR structural analysis of a novel triterpenoid saponin extracted from Bellis perennis L. Acta Chim. Slov. 2012, 5, 169-175. 